\title{
EL PARÍS DE HAUSSMANN COMO TERRITORIO DE LA \\ UTOPÍA: VICTOR FOURNEL (1865) Y VICTOR HUGO (1867)
}

\author{
Juan Calatrava \\ Universidad de Granada
}

\section{RESUMEN}

El resurgimiento del género político-literario de la utopía en las décadas centrales del siglo XIX, ligado a las nuevas condiciones de las metrópolis industriales, presenta en París un privilegiado territorio de aplicación, sobre todo en el momento de los grands travaux del barón Haussmann. Se analizan en este artículo dos textos especialmente significativos a este respecto: el Paris nouveau et Paris futur de Victor Fournel (1865) y la Introduction redactada por Victor Hugo para la Paris Guide editada con motivo de la exposición universal de 1867.

Palabras clave: Utopía, París de Haussmann, Victor Fournel, Victor Hugo

\section{ABSTRACT}

A phenomenon linked to the new conditions of the industrial metropolis, the resurgence of political and literary utopias in the middle decades of the 19th century found fertile ground in Paris, particularly at the time of Baron Haussmann's grands travaux. This article focuses on two texts that are especially meaningful in this respect: Victor Fournel's Paris nouveau et Paris futur (1865) and Victor Hugo's introduction to the Paris Guide, published for the 1867 Universal Exhibition.

Keywords: utopia, Haussmann's Paris, Victor Fournel, Victor Hugo

Uno de los más conocidos efectos culturales del nuevo universo metropolitano creado por la revolución industrial es el resurgimiento de un viejo género a un tiempo literario y político, la utopía, que experimentará a lo largo de todo el siglo XIX (en condiciones bien diferentes a sus dos brillantes fases previas, ligadas a la cultura del Renacimiento y al pensamiento de las Luces) una revitalización que le permitirá convertirse en vehículo privilegiado para un amplio cúmulo de reflexiones sobre los gigantescos cambios que estaba experimentando la sociedad occidental, y en especial sus ciudades'.

No puede sorprender que fuese precisamente París, verdadera ciudad-vórtice en la que tuvo lugar, en las décadas centrales del siglo XIX, el mayor experimento de transformación urbana de toda la centuria, uno de los laboratorios principales -si no el principal, junto con Londres- de la elaboración de las modernas formas de la utopía. Si del París decimonónico puede decirse que fue una ciudad construida con palabras tanto como con ladrillos o macadam, tal es la importancia de la elaboración literaria de su propio mito², las utopías -o distopías- parisinas constituyen en el seno de esta inmensa masa literaria una parcela bien específica, hasta el punto de hacer de París sin duda la urbe que mayor cantidad y diversidad de literatura utópica generó a lo largo del XIX. Simplemente ciñéndonos a los veinte años que transcurren entre 1850 y 1870, podríamos enumerar, sin llegar nunca a la exhaustividad, no 
menos de una cincuentena de obras de carácter utópico directamente ligadas a París, algunas de ellas de tanta trascendencia como las de Jacques Fabien ${ }^{3}$ o Jules Verne ${ }^{4}$.

Estas últimas son prácticamente contemporáneas de los dos escritos que van a ser objeto de análisis en este artículo, y esta proximidad cronológica no es en absoluto casual: es la brutal irrupción de unas transformaciones urbanas que trastocan por completo el sentido del tiempo lo que explica la especial concentración de reflexiones utópicas o distópicas justo en los años de los grands travaux de Haussmann. Tanto la pesadilla futura de Victor Fournel (1865) como el sueño optimista de Victor Hugo (1867) ven la luz en el momento culminante del Segundo Imperio, cuando esos cambios en la trama urbana de París que dejaban perplejo y dolorido a Baudelaire ya eran más que evidentes y el régimen se aprestaba a celebrar, con la exposición de 1867, el liderazgo de París entre todas las metrópolis europeas. Sin embargo, tanto Fournel como Hugo imaginaban un París futuro bien ajeno al triunfalismo oficial: si, para el primero, la prevista consolidación futura del haussmannismo no constituía motivo alguno de celebración sino todo lo contrario, para el segundo el futuro de París se disociaba claramente del odiado régimen bonapartista y se concretaba en una utopía pacifista y de unidad de los pueblos. Ambos autores no hacían así sino evidenciar las profundas grietas ocultas de ese edificio político que se derrumbaría estrepitosamente sólo algunos años después.

\section{5: Paris nouveau et Paris future de Victor Fournel}

Victor Fournel (1829-1894), prolífico periodista, ensayista, infatigable viajero y escritor sobre viajes, es una de las figuras literarias que encuentran todo su sentido en el contexto del París de Haussmann. Si posiblemente su calidad literaria no resiste la comparación con esos otros gigantes de las letras con quienes compartió el sentimiento de estupefacción ante la transformación acelerada de París, tales como Baudelaire, Théophile Gautier o, algo después, Émile Zola, sus obras resultan sin embargo de gran interés desde el punto de vista de la historia de los mitos urbanos y de su plasmación escrita.
Fournel, ya se ha dicho, es una criatura del París de Haussmann, que constituye la materia directa de algunos de sus libros y el telón de fondo de practicamente todos ellos, incluyendo sus propios libros de viajes, en los que la mirada a las realidades externas se hace siempre desde la comparación con el nuevo París. El juicio de Fournel sobre las célebres transformaciones de París es claramente negativo, aunque con frecuencia revestido de una ironía en apariencia celebrativa pero en la práctica demoledora. Dicho juicio se va formando y se declina en una serie de obras que se escalonan a lo largo de un periodo de más de treinta años que, en su primera parte, coincide casi exactamente con el desarrollo de los grands travaux del Barón Haussmann. Tanto sus descripciones urbanas como sus estudios sobre la población parisina y sus tradiciones retratan, casi como en una última mirada de adiós, el viejo universo urbano histórico, pintoresco y popular cuya desaparición constituía, para Fournel, el pesado precio que la ciudad pagaba por una modernización cuyas ventajas, por ejemplo en cuanto a higiene urbana, por otro lado, nunca cuestionará.

Ya en 1856, en Ce qu'on voit dans les rues de Paris, se hacía eco, en la senda abierta por Balzac en los años previos al inicio de los grands travaux napoleónicos ${ }^{5}$, de los nuevos grandes temas que la eclosión del universo metropolitano ponía sobre el tapete: la multitud, el flâneur, la movilidad incesante, el paisaje de ruinas y demoliciones, la fiebre constructiva, la aceleración de los ritmos de la vida, los cambios en el modo de vivir el tiempo o la desaparición de la ciudad tradicional en todas sus manifestaciones. En 1861, su contribución al segundo volumen de la obra colectiva, de claro carácter celebrativo, Paris dans sa splendeur ${ }^{6}$, no dejaba de incluir un claro tono crítico cuando, al redactar el capítulo VII, dedicado a los Établissements de plaisir, ironizaba sobre la entronización absoluta del principio del placer en el nuevo París (un tema sobre el que, como veremos, volverá también Victor Hugo).

En otras obras posteriores prosiguió con su tentativa de trazar un verdadero catálogo de las manifestaciones humanas ligadas a ese París histórico que estaba desapareciendo ante sus ojos o, sencillamente, formaba ya parte del pasado: 
Les spectacles populaires et les artistes des rues (1863), Les rues du vieux Paris. Galérie populaire et pittoresque (1879) o Le vieux Paris. Fêtes, jeux, spectacles (1887) constituirían, en el fondo, sendos capítulos de lo que podríamos considerar como una gran enciclopedia nostálgica de esa vida urbana tradicional y pre-metropolitana. En 1870 se alzó igualmente ${ }^{7}$, contra el proyecto haussmanniano no realizado de construir en Mery-sur-Oise un gran cementerio que reemplazaría a todos los camposantos de París y al que los difuntos y su cortejo llegarían en tren. Y cuatro años más tarde, tras las dolorosas pruebas de Sedán, el asedio prusiano y la Comuna, también se uniría Fournel al amplio coro elegíaco que se alzó sobre las ruinas de París y que, lejos ya de todo sentimiento estético de una "poética de las ruinas" al modo diderotiano, constituye todo un subgénero de la rica historia literaria de la ciudad.

En este panorama le corresponde un lugar especial a Les cris de Paris ${ }^{9}$, obra en la que el Fournel viajero que había recorrido Oriente Medio, España e Italia y hallado en esos pays du soleil no sólo un paisaje arquitectónico y urbano lleno de pintoresquismo, sino también un paisaje sonoro tradicional, traspone a París esa consideración verdaderamente pionera de la "sonoridad" como parte esencial de la historia de una ciudad ${ }^{10}$. Establece una contraposición neta entre un París moderno cada vez más mudo y la sonoridad tanto de las ciudades mediterráneas y orientales como de las propias urbes occidentales en los tiempos anteriores a los procesos de modernización, procesos que incluyen siempre una componente de uniformización sonora tan evidente como la de la propia geometría de las nuevas avenidas. Esa "sinfonía incesante" que caracterizaba a la ciudad histórica y que sigue caracterizando a la ciudad oriental o mediterránea no es, para Fournel, un simple ruido amorfo, sino verdadera música que traduce de un modo directo la complejidad y riqueza de la vida de sus habitantes. El avance de la modernidad significará, por contra, un proceso de creciente rarificación y eliminación de todas esas voces. Frente a la abundancia, la espontaneidad y la irregularidad que caracterizaban a les cris del París tradicional, el panorama sonoro del París haussmanniano se ha regularizado, acortado y oscurecido: tres términos textuales que condensan todo el abismo existente entre dos modelos de ciudad. En el ambiente sonoro de París, lo mismo que ha ocurrido en sus calles, "... se ha cortado a tijeretazos a través del hormigueo de la calle; se ha podado y aclarado este bosque" $" 1$.

Pero lo que nos interesa ahora comentar más por extenso es cómo en 1865, con la publicación de su Paris nouveau et Paris futur ${ }^{12}$, la mirada crítica de Fournel sobre la metrópolis haussmanniana se vuelca también en los moldes de ese amplio movimiento de resurreción de la utopía como género literario, político y urbanístico que se puede constatar en las décadas centrales del siglo XIX y que halla en el París en plena transformación uno de sus territorios privilegiados.

Lo primero que llama la atención en la particular utopía parisina de Fournel es el hecho de que la contraposición se establezca entre "lo nuevo" y "lo futuro". Si el discurso utópico implica necesariamente una visión crítica sobre el presente, la novedad de Fournel es lo absolutamente "nuevo" de ese presente, que no es otro que el que resulta de la nueva temporalidad introducida por la gran reforma urbana del Barón Haussmann y de la que tan consciente sería Charles Baudelaire'13.

Como en el resto de sus libros, su mirada sobre los míticos grands travaux está bien lejos de ser celebrativa (aún reconociendo en ocasiones, como se ha dicho, la bondad de algunos de los avances de la modernización, sobre todo desde el punto de vista higienista). El Paris nouveau, es decir, su propio París contemporáneo, a cuya descripción dedica la práctica totalidad de su obra es un París en el que se aúna la desaparición material de los restos del pasado (en un panorama lleno de demoliciones y ruinas nada poéticas) con la eliminación de unos modos de vida sobre los que se implanta la tiranía de la uniformización haussmanniana, simbolizada en el compás (que el propio Barón esgrimirá en algunas de las múltiples caricaturas de su figura aparecidas en la prensa satírica de la época) (Fig. 1).

El brillante análisis de Fournel de la transformación de París bajo el Segundo Imperio y sus consecuencias está aún a la espera de un análisis detallado que reconozca toda su importancia en el amplio conjunto de lo que podríamos llamar "literatura haussmanniana". Nos centra- 


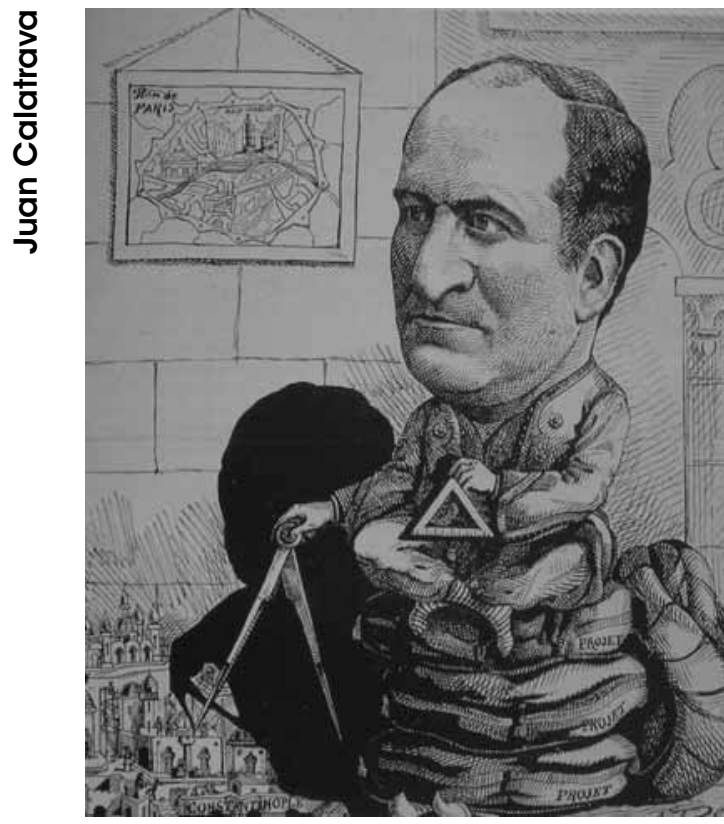

Fig. 1. Caricatura del Barón Haussmann imponiendo la geometría a París (publ. en Comic-Finance, Journal Satirique Financier, 1868)

remos ahora, sin embargo, en la parte más estrictamente utópica de su visión de París, la que consagra a la predicción de la vida en el París futuro de 1965. Aunque ésta ocupa apenas las 30 últimas páginas de su libro ${ }^{14}$, constituye una contribución esencial a la mitología de París, condensando apretadamente en ellas una verdadera distopía que nos viene presentada no como feliz contraposición al presente sino, bien al contrario, como la desgraciada consecuencia lógica de aquel París nouveau, en una ciudad que, cien años después, no hace sino exacerbar y llevar hasta sus últimas consecuencias las ideas y los principios urbanos puestos en marcha en el Segundo Imperio.

El arranque del Paris futur responde a un lugar común habitual en la literatura utópica: el protagonista, tras ser vencido por el sueño, despierta (como le había ocurrido al protagonista del Paris en songe de Jacques Fabien y como le ocurrirá, por ejemplo, en 1890, al personaje de las News from Nowhere de William Morris) en el mismo lugar, pero en el futuro. Es la misma persona la que contempla éste último con los ojos del pasado, la que establece la relación entre las tres temporalidades de pasado, presente y futuro, y el relato asume así la forma de una continua comparación entre un antes y un después que son también para el narrador sendos -aunque diferentes- ahora (que este "sueño" sea en realidad una pesadilla quedará claro, como veremos, al final de su periplo temporal).

El narrador despierta exactamente 100 años después, es decir, en 1965. Y su primer contacto con el París futuro asume, de nuevo, la forma de un tópico: el de la subida, de la mano de un ángel, a "lo alto de un monumento" 15 que no se especifica y desde el que puede abarcar una visión panorámica de la nueva realidad urbana. Dicha panorámica está marcada desde el principio por el sentimiento de asombro ante el crecimiento de París. La ciudad ha desbordado sus límites, hasta alcanzar los 100 kilómetros de perímetro y tener como nuevas puertas urbanas a Versalles, Pontoise o Chantilly, con el Arco de Triunfo -cuyo futuro imaginario en estado de ruina ya había constituido el tema del célebre poema de Victor Hugo al que más abajo se hará referencia- relegado a un papel secundario, mientras que el bulevar de Sebastopol, que había sido una de las piezas clave de los grands travaux de Haussmann, se ha prolongado hasta llegar prácticamente a Senlis. Esta amenaza de expansión la sienten muy claramente los habitantes de Meaux, que otean inquietos desde la torre de su catedral -una vez más, el punto de vista elevado- los avances de la "ola" de París. Otro de los resultados de esta ampliación es, por otro lado, el hecho de que en 1965 la vieja aspiración de "París puerto de mar" pueda ya considerarse a medio camino de realización ${ }^{16}$.

Este crecimiento está lejos, sin embargo, de ser visto como un hecho positivo o un factor de progreso: considerado por el autor como un "monstruoso cáncer" que ha roído toda la carne viva de la nación y ha reducido a Francia a la condición de banlieue de París, Fournel desgrana con ello un episodio más de la larga polémica París vs provincias, tan consustancial al debate urbano, territorial y cultural de la Francia contemporánea y que, como enseguida veremos, estará igualmente presente, aunque en sentido contrario, en la visión utópica de Victor Hugo ${ }^{17}$. 
Un hecho, sin embargo, parece poco acorde con esta extensión sin freno de París: el empeño de la ciudad por seguir marcándose nuevos límites claros. La presencia de un bulevar exterior circular que marca el contorno de la urbe, con un trazado que sigue inmediatamente por el interior al de las nuevas murallas, permite intuir un eco de la polémica que en fechas prácticamente contemporáneas comenzaba ya a suscitarse, en materia urbanística, entre los partidarios de la ciudad de crecimiento ilimitado y carente de barreras artificiales (como sería el caso del Plan Cerdà de Barcelona o, algo más tarde, el del plan de Otto Wagner para Viena) o los defensores del establecimiento de límites preestablecidos para este crecimiento. Sin duda, el hecho de que este París, al que se describe, en una metáfora oceánica (muy habitual en la "poesía de París" y desarrollada especialmente por Victor Hugo), como una ola que se derrama sobre todo el territorio circundante, haya optado por dotarse de un hito de inmovilidad, de una nueva barrera, llamada a ser inmediatamente franqueada, constituye el aspecto más contradictorio del planteamiento urbano del París futuro, reflejando las propias vacilaciones del incipiente debate urbanístico.

La ciudad que contempla Fournel en 1965 se muestra, ante todo, finalmente entregada a la geometría y a la estandarización más absolutas, hasta el punto de que hubiera podido suscitar, nos dice el autor, el éxtasis de Gaspard Monge. El París futuro constituye la culminación lógica del proceso puesto en marcha por Haussmann y puntualmente llevado adelante por seis generaciones de prefectos en su misma línea. Es el reinado del compás lo que garantiza, como señala con ironía el autor, que por fin el ojo ya no se sienta herido por la indisciplina de la iniciativa individual.

Ello se traduce, en primer lugar, en una ordenación urbana estrictamente geométrica y simétrica, fuertemente articulada en torno a los números 50 y 10. En efecto, desde una gran plaza central de una legua de circunferencia parten cincuenta bulevares radiales que llegan, en ininterrumpida andadura rectilínea, hasta el nuevo límite exterior de la urbe. Cada uno de estos bulevares tiene exactamente cincuenta metros de anchura y está bordeado por casas de igual- mente cincuenta metros de altura ${ }^{18}$. Diez bulevares circulares (en los que, se nos dice, la línea curva ha sido milagrosamente sometida a los mismos principios que la recta) cortan a intervalos regulares estas vias radiales, combinando la disposición concéntrica con la radial y suscitando encuentros en los que surgen las plazas de cuyo diseño arquitectónico se hablará más abajo.

Cada una de las calles de la ciudad es, igualmente, sometida a una división racional de su espacio de circulación, prefigurando propuestas urbanísticas que poco tiempo después se plantearían en esos mismos términos pero sin ninguna carga utópica (en especial, la calle de Fournel anticipa algunas de las ideas de Eugène Hénard ${ }^{19}$ ) (Fig. 2). El espacio indiferenciado de la calle tradicional, por el que compiten en desorden peatones con diverso tipo de andadura, circulación rodada, puestos de mercancías,

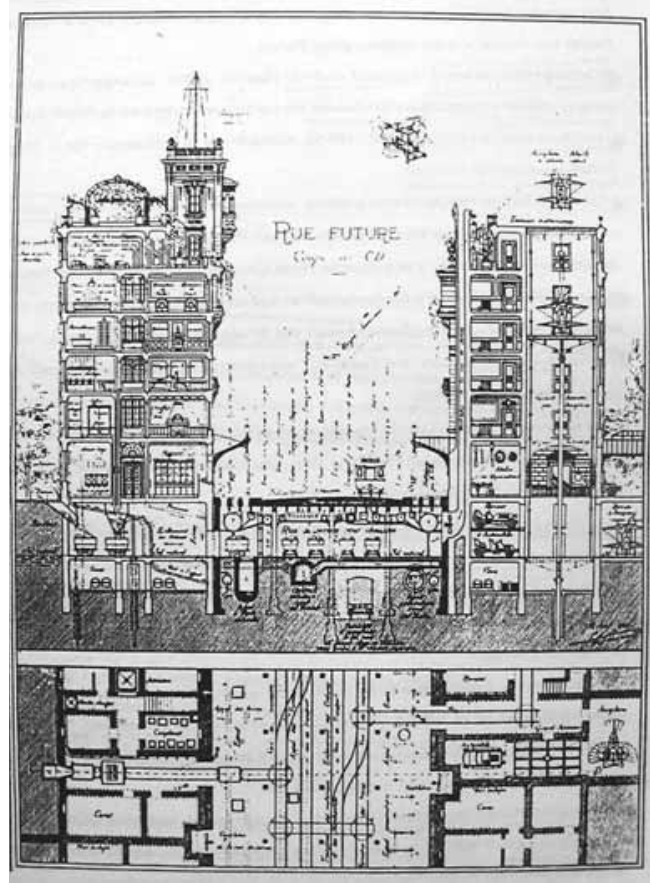

Fig. 2. Eugène Hènard, La calle futura (Études sur les transformations de Paris, 1903-1906)

etc., da paso ahora a una repartición geométrica y clara a partir de los modos de circulación: en cada extremo, una acera dividida en dos pisos para canalizar los dos sentidos de la marcha (ha- 
ciendo ya imposible ese encuentro azaroso -tan esencial en la literatura parisina del XIX, desde Balzac hasta Maupassant- entre dos personas que andan en dirección contraria); a continuación, a cada lado, una calzada para coches y carruajes; y en el centro, cuatro filas de raíles para los trenes que ahora cruzan París en todos los sentidos. A ello hay que añadir otro elemento especialmente significativo: los puentes volantes que permiten cruzar la calle sin correr esos riesgos físicos que tan penosos resultaban en 1865 en la ciudad dominada por los escombros, las zanjas abiertas, los pavimentos desventrados o el macadam ${ }^{20}$ (Fig. 3).

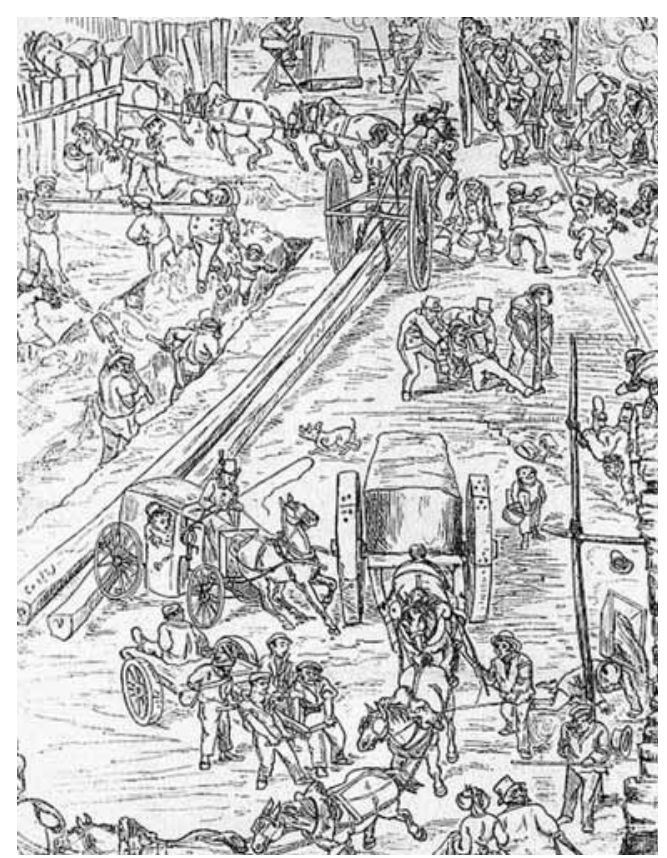

Fig. 3. Victor-Eugène Geruzez (Crafty), Les démolitions de Paris, publ. en Le Monde Illustré, 1868

Esas calles son objeto no sólo del orden geométrico sino también de lo que ya desde los urbanistas de las Luces se consideraba como su correlato esencial: el higienismo, capaz de desterrar ese otro elemento de desorden que eran las "miasmas". Como en practicamente todas las utopías del XIX21, la limpieza es obsesiva. Cada de una de las vías de París es tomada cada noche por un ejército de operarios de limpieza equipados con máquinas de vapor. $Y$ en esta misma línea hay que entender la mención expresa a las "vespasianas", es decir, esos urinarios públicos, símbolo de la novedosa atención al mobiliario urbano, que justo en el mismo año de la aparición del libro de Fournel habían constituido el insólito tema de algunas de las más conocidas fotografías de Charles Marville (Fig. 4).

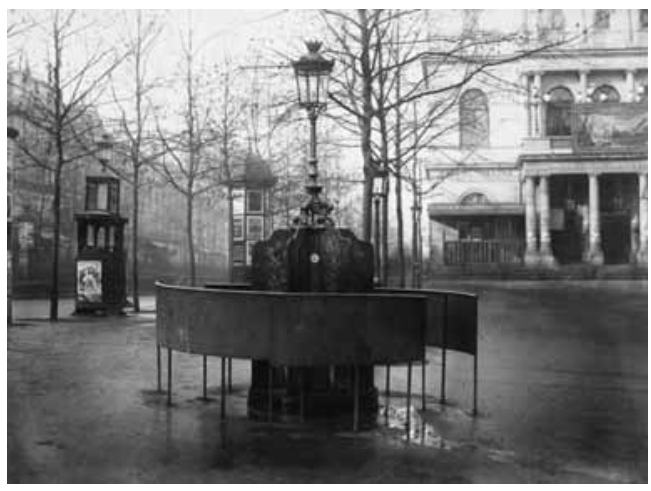

Fig. 4. Charles Marville, fotografía de una "vespasiana", 1865

Igualmente llamativa es la evolución a la que ha llegado en 1965 el amplio sistema de verde urbano diseñado por Haussmann y su mano derecha en este ámbito, el ingeniero Jean-Charles Alphand, es decir, la red jerarquizada que los grands travaux habían puesto en pie (desde los gigantes Bois de Boulogne y Bois de Vincennes hasta los más pequeños squares, pasando por unidades intermedias como los parques de Buttes-Chaumont o Montsouris). Este es el aspecto en el que en mayor medida el París de 1965 desmiente la herencia haussmanniana, porque está claro que en ese París futuro la naturaleza, por controlada que esté, no deja de ser un inquietante factor de variabilidad y desorden, además de un despilfarro de espacio. Así, el jardín del Luxembourg aparece ahora atravesado por una serie de bulevares que sacan rendimiento de lo que antes era suelo inútil. Y, sobre todo, los squares se toleran ahora únicamente como una concesión para las pocas "almas románticas" que quedan, pero no se plantan con las artes de la jardinería urbana sino que ahora se encargan ya completamente confeccionados a empresas especializadas que los realizan en cartón pintado y equipados incluso con pájaros artificiales: «Así, se había conservado lo que hay de agradable en la naturaleza evitando lo que hay de sucio e irregular»»22. 
La exigencia absoluta de uniformidad se traslada, asimismo, de la escala urbana a la arquitectónica, ya que cada casa tiene exactamente cincuenta ventanas y la decoración de las fachadas es absolutamente idéntica. Casi podría decirse que la arquitectura de la que está construido el París de 1965 es procustiana: en su obsesión por ceñirse a la rigurosa organización geométrica de la ciudad, no tiene en cuenta ni las necesidades de sus habitantes ni los usos a los que los edificios están destinados. Una de las grandes paradojas de la supuesta racionalidad de la urbe es la existencia de edificios vacíos, que no sirven para nada, cuya existencia se justifica únicamente por el mantenimiento del orden geométrico y que, pese a todo, disponen de su correspondiente dotación standard de personal.

Por otro lado, no deja de llamar la atención el hecho de que la equitativa distribución de aire puro (garantizada por la presencia en cada casa de un "aerómetro") no se considere incompatible con la existencia de una profunda jerarquización social, nunca cuestionada. Ésta se da tanto en sentido vertical (en los tejados de cada casa se alzan pabellones mucho más baratos que los demás pisos) como horizontal, con una clase obrera que vive extramuros y que se ve obligada a recorrer cada día 5 ó 6 leguas para ir al trabajo. Nada hay, pues, en el París de 1965 que recuerde el carácter igualitario característico de muchas utopías.

Coherentemente con ello, el París futuro es también una ciudad absolutamente controlada desde el punto de vista militar, con lo que Fournel se alinea con quienes desde el principio veían en los grands travaux esas finalidades estratégicas que más tarde constituirían el núcleo de la conocida interpretación benjaminiana. El nuevo París de 1965 es un espacio cuya disposición urbanística hace ya prácticamente imposible cualquier revuelta y ha permitido conjurar definitivamente los fantasmas de 1848. En la plaza central, un cuartel circularabre en sus muros cincuenta aberturas que permiten que cada uno de los cincuenta bulevares radiales quede enfocado por la boca de un cañón. Desde este cuartel, los centinelas que vigilan el orden urbano con un dispositivo panóptico mantienen con sus homónimos de los puestos militares ubicados en las barreras exteriores una continua comunicación visual (mediante aparatos ópticos) y también telegráfica, asegurando así la notificación inmediata de cualquier posible desorden.

Acerca de en qué podrían consistir tales posibles desórdenes nos da, por lo demás, una pista la iconografía del relieve que decora el muro de este cuartel (del que se nos informa que es "monumental"): una imagen del Orden Público derrotando a la hidra de la Descentralización. Ese París "centrado" no es mera geometría sino trasunto de una visión política igualmente geometrizada: la que preconiza el mantenimiento de la larga preeminencia parisina sobre el conjunto de la nación.

Símbolo máximo de esta moderna capacidad de control es igualmente la iluminación universal, la definitiva culminación del proyecto moderno del triunfo de la luz sobre las tinieblas. En el París de Fournel, un inmenso faro eléctrico ilumina todo París desde este área central, cancelando la distinción entre día y noche y negando cualquier lugar, ni siquiera residual, para lo oscuro, lo oculto o lo misterioso. $Y$ es bien indicativo de la corta distancia existente en el París de la segunda mitad del XIX entre utopía y proyectos considerados realizables el hecho de que en la década de los 80 , en el marco de los proyectos de torres para la exposición de 1889, el arquitecto Jules Bourdais presentara su propuesta de una gran torre-faro, significativamente denominada la Tour-Soleil, de 360 metros de altura susceptible de iluminar completamente París desde una sola y poderosa fuente lumínica central, desterrando el sistema de alumbrado de gas del que por entonces se enorgullecía la ciudad y que haría posible el surgimiento del mito del Paris-la-nuit²3.

¿Y qué ocurre con el rico pasado histórico de París? La mayor parte de él ha desaparecido, tras sucederse, después de Haussmann, no menos de seis prefectos aquejados del mismo «delirium tremens» de la demolición y de la misma «monomanía furiosa» de las nuevas construcciones. Las antiguas fortificaciones, desde los restos de las murallas medievales hasta el muro de Thiers, han sido destruidas y ya constituyen sólo un tema de disertación para los arqueólogos que todavía se apegan al pasado. Del mismo modo, los viejos faubourgs, con sus rasgos individuales, 
han desaparecido, arrasados por el avance imparable de los bulevares. E igual ha sucedido con la mayor parte de esos edificios góticos a los que en 1865 todavía salvaba un resto de superstición (tan sólo en las vespasianas pueden aún verse "torrecillas góticas"). Al menos la catedral de Nôtre-Dame sigue existiendo, pero "...a fuerza de restauraciones parecía por fin presentable" ${ }^{24}$.

Y la censura sobre el pasado se ha ejercido incluso sobre la propia toponimia de la ciudad, ya que en 1965 se han desterrado todos los nombres de calles que contuviesen la más mínima alusión al viejo París, su historia o sus personajes. De hecho, las calles del París futuro han sido objeto de una calculada operación de re-denominación que ha convertido la lectura de sus placas en un gran "cuadro mnemotécnico", en una transparente lección, lógica y ordenada, de la geografía y de la historia de Francia.

Sin embargo, el París futuro no ha desterrado por completo el valor del monumento ni la idea misma de monumentalidad, sino que la ha sometido a los nuevos principios del orden racional. El nuevo monumento coherente con el París de la geometría puede encontrar un lugar propio a través de dos vías.

La primera es la realización ex novo de verdaderos monumentos modernos, en los que el valor conmemorativo va siempre acompañado de una directa utilidad urbana. Así, en el emplazamiento del Mont-Valérien se ha alzado una nueva versión del Coloso de Rodas, de cuyos pies irradia una ramificación de conducciones de agua, y en Montmartre (anticipando el papel de hito que, tras la Comuna, desempeñara la basílica expiatoria del Sacre-Coeur) una gran cúpula con un inmenso reloj visualiza el sometimiento total de la ciudad al nuevo tiempo del capital.

Es el caso también de la nueva plaza acristalada que en 1965 ocupa el emplazamiento del ex-jardín de las Tullerías. En ella aparece un gigantesco invernadero que parece llevar a su culmen la historia tanto de los pabellones de exposiciones universales como de esos pasajes comerciales acristalados que fueron elevados por Walter Benjamin al rango de metáfora por excelencia de la metrópolis decimonónica ${ }^{25}$. En las cuatro esquinas de esta gran plaza vítrea se suceden los cuatro monumentos-tipo que, según los nuevos gestores de la ciudad, constituyen el resumen de una gran capital: alcaldía, cuartel, teatro y bolsa. Y, en su centro, se alza una gran estatua -que es también calorífero y fuente- del propio Haussmann, definido como el "segundo fundador de la ciudad", el prefecto que venció "las tinieblas y las resistencias del viejo París": con una mano sobre el plano de París y la otra con un compás abierto (justo tal y como lo representaban algunas de las más críticas caricaturas contemporáneas a su gestión).

Pero hay también una segunda vía, mucho más original y podríamos decir que "utópica", de gestión de lo monumental: la que ha llevado a trasladar y reubicar una serie de edificios antiguos salvados de la demolición para constituir un nuevo escaparate racional y ordenado. Dichos monumentos -antiguos stricto sensu pero de los que igualmente se podría decir que son nuevos como resultado de su manipulación- se encuentran artificialmente alineados (gracias a la invención de una maquinaria que ha hecho posible su desplazamiento) en el perímetro de las sucesivas plazas que se abren en las intersecciones entre los cincuenta bulevares radiales y los diez bulevares concéntricos.

Con este gigantesco traslado de edificios histórico se ha puesto fin, así, a lo que se consideraba una arbitraria dispersión intolerable, pero además se ha facilitado y racionalizado con ello la actividad de una figura que también cambia de sentido en este nuevo París: el turista o el viajero. En efecto, esta reordenación de los monumentos los sitúa en unas líneas lógicas tan claras como las de los omnibus. El viajero de 1965 ya no puede perderse ni "flanear": de su andadura están ahora ausentes la sorpresa o el descubrimiento, porque la ciudad geométrica es transparente y no precisa de operaciones de desciframiento ni de orientación (ni tampoco de guías turísticas, inútiles en una ciudad que ha hecho de sí misma su propia guía hasta el punto de poder ser directamente legible sin mediaciones).

El París futuro que nos describe Fournel es, en realidad, una exposición universal permanente, eco de las grandes exposiciones reales que habían tenido lugar en 1851 en Londres y en 1855 en el mismo París. Pero en esta ciudad en permanente exhibición el haussmannismo ha al- 
canzado ya los más extremos límites en cuanto a uniformidad y geometrización. El París de Fournel, heredero directo de Haussmann, ese "Atila de la línea recta", cuya actuación es comparada a la de los fautores del Terror del 93, quizás no llegue aún a constituir una distopía en el sentido estricto del término, pero, con su carácter de crítica directa a los procesos urbanos contemporáneos, constituye claramente un caso especial dentro del género utópico del XIX.

El despertar suscita la duda de si ha sido sueño o pesadilla, y la confirmación de lo segundo cuando, después de recibir el impacto sensorial del estrépito de la calle y el polvo de las demoliciones, el criado le entrega un aviso (el tercero en poco tiempo) de desalojo de su vivienda por inminente llegada de las obras.

\section{7: Victor Hugo y la Paris Guide}

Desde Nôtre-Dame de Paris (1832) a Les Miserables (1862) o al texto que centrará aquí nuestra atención, la Introduction a la Paris-Guide editada con motivo de la exposición universal de $1867^{26}$, puede afirmarse que la reflexión sobre París constituye uno de los ejes primordiales de la poética de Victor Hugo. Así, en su ya clásico y monumental estudio sobre la "poesía de París", Pierre Citron deslindó detalladamente los jalones que van marcando en la obra de Hugo un itinerario -complejo y nada lineal- que culminará en la definitiva consagración del París futuro como territorio de la Utopía. Del mismo modo, más recientemente, Karl Heinz Stierle ha destacado cómo la mirada de Hugo compone, junto con las novelas de Balzac, el gran binomio sobre el que se basa la construcción literaria del mito de París en el siglo XIX.

Esta vinculación de la poética de Hugo a su escenario arquitectónico y urbanístico no hace sino aumentar y diversificarse con el tiempo, desde sus primeras preocupaciones de orden estrictamente patrimonial27 hasta sus últimas miradas sobre París como organismo. El primer gran monumento de ese itinerario es, por supuesto, Nôtre-Dame de Paris y sus dos célebres capítulos Paris à vol d'oiseau y Ceci tuera cela ${ }^{28}$, pero a él seguirán otros muchos jalones en este continuo ir y venir entre literatura, arquitectura y ciudad. Así, por mencionar sólo algún ejemplo de un recorrido imposible de abarcar aquí, habría que recordar como otro de los hitos de la mirada hugoliana sobre París el poema À l'Arc de Triomphe, escrito en 1834 pero publicado en 1837 en Les Voix intérieures ${ }^{29}$. Es igualmente en Les Voix intérieures donde Hugo habla de la "belleza" de la multitud de París, cuyo movimiento compara con el flujo y el reflujo de las olas en una metáfora marina a la que recurrirá repetidas veces como imagen de la ciudad: de hecho, la metáfora "París-océano" la volveremos a hallar en un texto que fue escrito originariamente para la Introduction a la Paris Guide de 1867 pero que fue descartado y reutilizado después, en 1875, como conclusión de Ce que c'est que l'éxil.

Pero sin lugar a dudas el gran monumento parisino de Victor Hugo es, treinta años después de Nôtre-Dame de Paris, Les Misérables ${ }^{30}$, una obra cuya proximidad tanto cronológica como temática al texto de 1867 merece que nos detengamos algo más en ella. En el París de Les Misérables hay un continuo deslizamiento temporal entre el París de ayer y el de hoy, el que corresponde al tiempo de la escritura del relato. A menudo el narrador hace una pausa e interviene en primera persona para cambiar de época y recordarnos que, en el momento de la lectura, la mayoría de los lugares que menciona ya han desaparecido. $Y$ es que la ciudad se ha vuelto panóptica, como profetiza Fournel, y nada en ella se opone ya al escrutamiento de los nuevos Javert. La larga historia de fugas y ocultamientos de Jean Valjean era posible en la década de 1830, pero imposible en el París de Haussmann.

Por lo que respecta a nuestro tema, hay que recordar cómo la fuerte carga utópica de Les Misérables fue perfectamente captada desde el mismo momento de su aparición. Baste el ejemplo de Alphonse de Lamartine, el poeta-político que no dudó en situar al gran fresco hugoliano como un hito del filón utópico que iba desde Platón a Rousseau o Fourier ${ }^{31}$, aunque destacando negativamente los efectos politicamente muy peligrosos de una utopía que convertía al hombre en enemigo de la sociedad en que vivía.

Esta dimensión utópica, diseminada de modo implícito pero esencial en la economía de lo que a primera vista podría parecer un simple fresco histórico, se hace explícita en determi- 
nados momentos clave de la trama, desviando la mirada del lector desde los acontecimientos presentes hacia el futuro. Es lo que ocurre, por ejemplo, con el mesiánico discurso de Enjolras en la barricada de 1832, en el que pronostica el porvenir de una humanidad que ha desterrado el mal y se guía unicamente por el amor y el pacifismo ${ }^{32}$. Y un poco más adelante, es el propio Enjolras, dirigiéndose de nuevo a sus compañeros de barricada, el que contrapone la lucha sangrienta del presente con el futuro esplendoroso que esa sangre comprará, introduciendo ahora nuevas declinaciones de esa utopía futura ${ }^{33}$. En el nuevo París que Enjolras parece incluso poder vislumbrar desde su atalaya en "lo alto de la barricada" se conjuga la herencia ilustrada del paradigma de la luz que disipa las tinieblas (calles "inundadas de luz") con el filón mesiánicocristiano centrado en torno a la idea de hermandad, pero también con las nuevas exigencias políticas agrupadas en torno al sintagma de la libertad. La nueva sociedad habrá desterrado también los mitos que atenazaban de miedo al hombre y habrá puesto en su lugar a la ciencia, en un proceso ya iniciado en su propia época ${ }^{34}$. Algo más adelante, es el propio narrador el que inserta, en el clímax del inminente ataque a la barricada, una defensa de la utopía en su difícil relación con la violencia necesaria para construir un nuevo mundo: para hacer llegar la verdad del mañana, a menudo tiene que recurrir a una herramienta que se quiere relegar al pasado, cual es la guerra35.

Pero hay en Les Misérables un lugar que concentra, como auténtico vórtice telúrico y temporal, los tiempos pasado, presente y futuro de la ciudad: las alcantarillas, el submundo que protagoniza la huida desesperada de Jean Valjean llevando a cuestas a Marius y que da lugar a la más larga disgresión de historia urbana de la obra, hasta el punto de ocupar todo el libro Segundo de la Quinta Parte. Para Hugo, que recurre a estudios precedentes como el análisis higienista de Parent-Duchatelet ${ }^{36}$, la historia de las cloacas es un claro reflejo de la historia de los hombres, y la reconstruye para su lector de 1862 desde su oscuro pasado y los primeros e incompletos intentos de racionalización hasta el presente haussmanniano ${ }^{37}$. En el nuevo París, después de la gran epidemia de cólera de 1832, la alcantarilla es limpia, fría, "respetable" y hasta hermosa (calificativos con los que Hugo parece anticipar el hecho de que durante la exposición de 1867 las cloacas de París fuesen objeto de visitas turísticas), y ha asumido un aspecto casi oficial y administrativo, al precio de haber desterrado cualquier rasgo de su "primitiva ferocidad" y de haberse convertido en un lugar que Villon jamás podría ya reconocer. $Y$ en cuanto al futuro, Victor Hugo lo centra en el aspecto científico, considerando definitivamente desterrado todo atisbo poético: los colectores de París se beneficiarán de perfeccionamientos técnicos que permitirán lavar por completo los detritus, restituir el fango al suelo parisino y reciclar como abono los desechos humanos, poniendo fin así al despilfarro económico que marcaba a la alcantarilla tradicional.

En 1865, sólo tres años después de que la cultura francesa se viese sacudida por la aparición de Les Misérables, se decidió la celebración para 1867 en París de una nueva gran exposición universal, que venía a suceder a la de 1855, primera de las cinco ferias mundiales que albergaría París a lo largo del siglo XIX (1855, 1867, 1878, 1889 y 1900). Tras iniciar Londres en 1851, con el Crystal Palace de Paxton, la brillante serie de estos eventos que simbolizan a la perfección la complejidad de la cultura urbana decimonónica, París había tomado el relevo sólo dos años después del coup d'état que había inaugurado el régimen del Segundo Imperio. Pero, si aquella feria de 1855 había servido para apuntalar la popularidad del gobierno imperial naciente, doce años más tarde, en 1867, la nueva Exposición surgía en un contexto mucho más complejo en el que el Segundo Imperio parecía tocar la cumbre de su gloria pero eran también ya muchas las miradas críticas que apreciaban fallas en el imponente armazón político y socio-económico, al tiempo que se entreveía el inevitable enfrentamiento con la Prusia de Bismarck. De hecho, el año antes, en 1866, las tropas prusianas habían aplastado en Sadowa al tan brillante como anticuado ejército austriaco, dejando claro cuál era la gran potencia centroeuropea en la segunda mitad del XIX. Los mismos cañones Krupp que acababan de hacer estragos entre las filas austriacas se exhibirían en París en 1867 en las galerías elípticas concéntricas diseñadas por Krantz 
y Eiffel, y, al mismo tiempo que celebraban el progreso tecnológico, no dejaban de constituir una advertencia sobre los efectos perversos de tales progresos. Sólo tres años después esos mismos cañones estarían disparando sobre el París sitiado que iba a vivir la doble prueba del asedio y de la Comuna (Fig. 5).

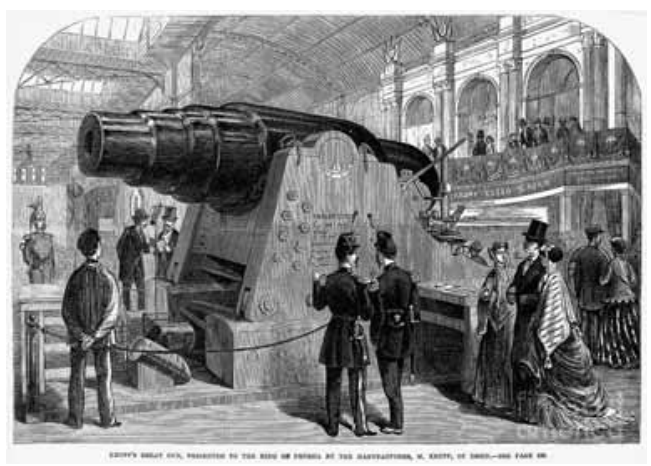

Fig. 5. Los cañones Krupp en la Exposición universal de París, 1867

La exposición de París de 1867 representaba, en su plasmación arquitectónica, ese fuerte carácter de utopía realizada que ya había estado patente en el Crystal Palace de Londres. El edificio principal, con su planta oval compuesta de anillos concéntricos de metal y vidrio, no se parecía a ningún otro tipo de construcción previa y representaba rodeando un jardín central con el Pabellón de los Pesos y Medidas, ese mismo afán uniformizador que exaltará Victor Hugo en su texto. La proeza técnica de esa arquitectura ingenierilse ponía al servicio del nuevo ideal burgués industrial y recuperaba, desde los esquemas del optimismo del progreso, la contraposición entre la ciudad real y esa otra ciudad a un tiempo efímera e ideal que permitía soñar con el advenimiento de una nueva era de abundancia y sin conflictos sociales (Fig. 6).

Esta magna exhibición del esplendor del París del Segundo Imperio exigía un monumento literario de similar grandeza. La Paris Guide apareció en mayo de 1867, por iniciativa de Paul Meurice, amigo, colaborador y habitual corresponsal de Victor Hugo. Meurice traspasó la idea al librero bruselés Albert Lacroix y, más tarde, fue apartado de la coordinación de la empresa en favor del francmasón Louis Ulbach. El resultado final

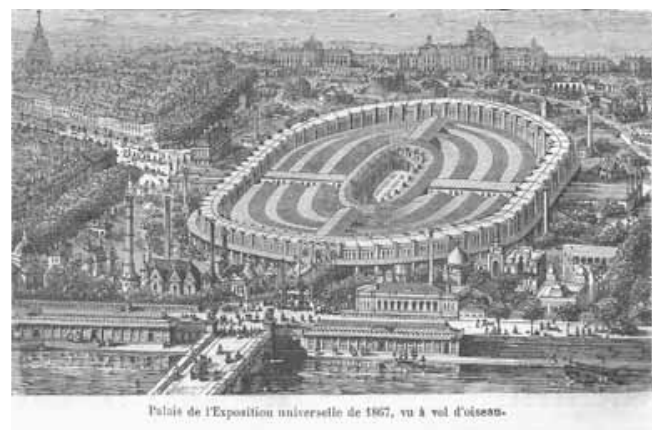

Fig. 6. Jean-Baptiste Krantz y Gustave Eiffel, Palacio de la Exposición Universal de París de 1867

fue un impresionante conjunto de dos grandes volúmenes, que se vendían al elevado precio de 10 francos con un total de más de 2.000 páginas y un brillante elenco de autores entre los que se encontraban, además del propio Hugo, nombres como Ernest Renan, Michelet, Gautier, Arsène Houssaye, George Sand, Alexandre Dumas, Edgar Quinet, Viollet-le-Duc o Hyppolite Taine, con ilustraciones que en principio se pensó que fueran todas de Philippe Burty pero que luego se encargaron a diversos artistas, entre ellos Felicien Rops. Esta monumental mirada colectiva sobre París será descrita por el propio Hugo, en su texto introductorio, recurriendo a esa misma metáfora arquitectónica que cincuenta años más tarde llevaría a Proust a hablar de su Recherche como una "obra-catedral" 38 . Hugo veía la Paris Guide como: "Un edificio construido por una deslumbrante legión de ingenios: éso es lo que es este libro" ${ }^{39}$.

Para escribir la introducción general a este "edificio", un texto que, según confesaría más tarde en Choses vues, le había costado tanto esfuerzo como una novela, Victor Hugo interrumpió la redacción de la obra que le ocupaba en ese momento, L'Homme qui rit, y la versión final no llegó (a finales de 1866) hasta que tuvo ocasión de leer las pruebas del resto de las contribuciones.

En 1867, Hugo llevaba ya 16 años en el exilio en Guernesey, con lo que carecía de un conocimiento directo de las transformaciones de la ciudad y, aunque demuestra estar perfectamente informado de los cambios (como se puede apreciar en Les Misérables), no es menos cierto que con frecuencia hace una cierta ostentación de 
falsa ignorancia, dejando bien claro que el París de su memoria es el inmediatamente anterior a Haussmann. Su París es en gran medida un espejismo de exiliado, un desideratum marcado por una fortísima carga tanto de nostalgia como de utopía: es la crítica acerba a los grands travaux de Haussmann la que le lleva a lanzar una doble mirada tanto al pasado histórico de un París aún no sometido a la tiránica geometría como a un futuro en el que la utopía reviste, ciertamente, formas más políticas que urbanísticas ${ }^{40}$.

Es esa mezcla entre el rechazo al París monótonamente regularizado y la inquebrantable confianza en un futuro político inmediato en el que la ciudad asumirá el papel de faro de los pueblos lo que explica que nos encontremos ante un texto apasionado, marcado en muchos momentos por un tono profético. Desde luego, las palabras de Hugo van mucho más allá de lo que cabría esperar de un mero prefacio y no constituyen en absoluto una celebración del presente sino una llamada a un futuro que, en buena medida, contradice de manera paradójica la triunfalista filosofía oficial de la exposición de 1867.

El texto se inicia con una inversión temporal sorprendente. El itinerario del discurso no procede según una temporalidad lineal: al contrario que en Nôtre-Dame de Paris, la visión de Hugo en 1867 comienza por el futuro, no por el pasado. Hugo había sido, de hecho, muy explícito sobre el papel central del tiempo en su mirada de 1867 sobre París ${ }^{41}$. Pero en la estructuración definitiva el pasado viene después, y se explica por el futuro. Y, comprimida entre ambos, la mirada crítica sobre el presente parece tan sólo el desencadenante de una utopía presentada no como aspiración irreal sino como conclusión lógica de la historia de la ciudad.

Como ya se ha anticipado, el futuro -no lejano- de París es contemplado a partir de una estricta coherencia entre organización territorial y urbana y nueva estructuración política. Para Hugo, el París del futuro es, ante todo, la ciudad de la paz, la ciudad que se ha vuelto indiferente a las glorias bélicas (tanto a las ajenas, como Sadowa, como a las propias, representadas en esa oscilación de fortuna que marca el binomio Austerlitz / Waterloo o el más reciente recuerdo de Sebastopol y el horror que supone la inclusión del recuento exacto de las víctimas de la guerra de (rimea) ${ }^{42}$.

La paz, sin embargo, no es un mero sentimiento humanitario que deje intacto todo lo demás. Bien al contrario, este nuevo pacifismo es inseparable de un triunfo de la ciencia sobre la política, que, en la línea del pensamiento sansimoniano ${ }^{43}$, quedará "reabsorbida" en la primera. Ello conllevará la existencia de una legislación lo más cercana posible al derecho natural, un rasgo de clara filiación rousseauniana que constituye un rasgo atípico de la utopía de Hugo: el principio de mínima intervención del Estado, frente al dirigismo estatal de un buen número de utopías. El Estado de la futura Europa hugoliana se limitará practicamente a garantizar la circulación y la seguridad, así como la básica unidad de moneda, pesos y medidas, y, en general, de "la norma" frente a la especificidad.

Lo que el autor contempla -porque, en efecto, Victor Hugo ya "ve", vislumbra en el horizonte el surgimiento de ese nuevo París- es, ante todo, la "visión majestuosa" de una nación europea única, cuya indiscutible capital es París y de la que ha desaparecido todo tipo de fronteras, peajes o trabas de cualquier tipo (ya sea físico o fiscal) a la circulación de personas, de mercancías y de ideas.

En esta gran nación nueva, frente a la estabilidad que siempre deriva en estancamiento, lo que predomina es la movilidad en todos los órdenes de la vida. Es una Europa en la que los grandes cursos fluviales han dejado ya de servir como fronteras o barreras entre los pueblos y se han convertido en arterias que vehiculan esos incesantes flujos. En ese futuro inmediato, la circulación engendra riqueza y hace realidad a escala europea la imagen bíblica de la multiplicación de los panes y los peces. Con ello París no hace sino dar continuidad a su vocación histórica de ciudad en perpetuo movimiento: no en vano es una ciudad siempre odiada por todos los que propugnan la inmovilidad de la vida, porque "... ser París es marchar" 44

La movilidad, sin embargo, no se limita al interior de esa nueva Europa. Para Hugo, que escribe su texto en un momento clave de consolidación de los grandes imperios coloniales británico y francés, un aspecto esencial del inme- 
diato futuro lo constituye la puesta en marcha de un nuevo modo de colonización civilizada, que llevará pacificamente a las masas desde las cités-mères europeas a las vastas extensiones de América, Asia, África y Australia. Se trata de una "dispersión fecunda" de la población por el territorio, desde esas colmenas que son las ciudades europeas, y a la que no escapa ningún rincón del globo que, como plasmación del ideal faústico, deviene en su totalidad "casa del hombre". Y el medio técnico que permite poner en práctica la utopía de esa diseminación pacífica de la población europea por el resto del mundo no es otro que la navegación aérea: Victor Hugo vislumbra un cielo poblado de aeronaves, integrando así su discurso en ese genérico mito de la conquista del aire que constituye un elemento esencial de las visiones utópicas del momento y que sería algunos años más tarde objeto tanto de las propuestas urbanas de Eugène Henard (con sus bloques de viviendas dotados de garajes para aeroplanos) como de las ilustraciones satíricas de Albert Robida (Fig. 7).

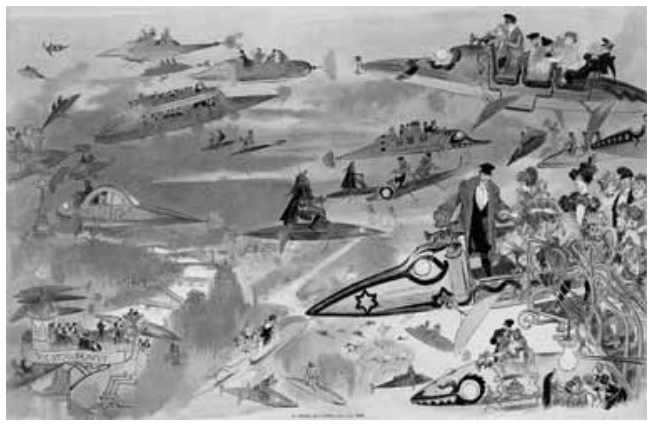

Fig. 7. Albert Robida, La salida de la Ópera en el año 2000, h. 1882

Y es que, ante todo, el París futuro ha puesto la técnica moderna al servicio del hombre: en él, la pólvora no servirá ya para cebar el cañón sino como auxiliar de las gigantescas obras públicas que contribuirán a la felicidad general. Es, sin duda, la cara amenazadora de la moderna técnica la que pretende conjurar Victor Hugo con su canto a un París pacifista, internacionalista, democrático, cuna de todas las fraternidades y capaz de erigirse en capital del mundo por la simple fuerza de atracción de su cultura humanista. Por eso, un poco más adelante, el capítulo dedicado a "La supremacía de París" incluirá una desesperada apelación al carácter "pacificador" de todos los progresos técnicos de nuestro tiempo (telégrafo, prensa, vapor, ferrocarriles, sistema métrico unificado...). Esa implantación de la tecnología más moderna se revela también en otro cambio cargado de simbolismo: el París futuro pondrá fin al alcantarillado tradicional, sustituyéndolo por un sistema de drenaje que permita sacar todo ese provecho económico de los residuos que ya se postulaba en Los Miserables.

Paradójicamente, es ese futuro de París el que nos explica el pasado de la ciudad. Si en los orígenes mismos de cada ciudad está ya inscrito, según Hugo, su carácter futuro (en una alternativa que oscila entre monstruo y prodigio, o entre barbarie y civilización), es la rica historia de París la que, a partir de unas primeras fases de indecisión, permite enseguida leer un avance hacia la condición de prodigio (avance que, no obstante, no es lineal y admite momentos de duda o de retroceso). Es una historia llena de antigüedad, pero no de una antigüedad tranquilizadora y ordenada, que pueda ser objeto de la mirada fría del anticuario, sino de un pozo de tiempo vertiginoso: quien intente remontarse hasta sus orígenes más lejanos, donde la historia se diluye en el mito, es rápidamente presa del vértigo. Se trata de una historia compleja, y para describir dicha complejidad Hugo recurre a metáforas -muy habituales en su obra literaria- ligadas a las ideas de lo profundo, básicamente desde el paradigma geológico (acumulación de estratos, capas de aluvión...), de lo intrincado (espirales y laberinto) o de lo abismal (el pasado de París como un precipicio lúgubre al que el propio Dante dudaría en descender).

El París histórico que Hugo presenta a sus lectores de 1867 se hace eco de las reflexiones de Michelet o de los progresos de la arqueología parisina (de cuyos avances venía informando, por ejemplo, desde 1861, en su Statistique monumentale de Paris, Albert Lenoir, antiguo colega de Hugo en la Commission des arts et monuments), pero no constituye ni una lección de historia ni un informe arqueológico, sino el fundamento para una utopía de orden político. En esta inmensa potencia de estratos depositados por los siglos, verdadera "catacumba" de tiempo en la que se apilan las osamentas de todas las supersticiones, los fanatismos y las iniqui- 
dades, las guerras, las revueltas y las hambrunas, cualquier tentativa de simple excavación aparece condenada al fracaso. Y a ello también contribuye la relevancia histórica que asumen hechos aparentemente menores, hechos a menudo enigmáticos, susceptibles de diversas interpretaciones, y que requieren del historiador no la frialdad notarial sino una labor de desciframiento similar a la del interrogatorio de la Esfinge.

El efecto de superposición, en esa ciudad que es literalmente un palimpsesto ${ }^{45}$, asume también la forma del ejercicio propuesto por Hugo de superponer los planos históricos de París unos sobre otros. Ello permite comprender en toda su medida el espectacular crecimiento de la ciudad, en la descripción de cuyas fases vuelve el autor a utilizar trozos literales de lo que ya había escrito en 1832 en el famoso capítulo Paris à vol d'oiseau de Nôtre-Dame de Paris. Sesenta años más tarde, Walter Benjamin recogería el reto de Hugo permitiéndose soñar con la realización de una película basada en los planos de París ${ }^{46}$.

Esta historia parisina, por lo demás, no es, en absoluto, un mero hecho local, sino que adquiere a lo largo de su desarrollo secular un claro sentido universal, capaz de hacer que la ciudad se convierta en metáfora del destino de toda la humanidad. De ahí que desde el principio aparezca clara la idea de relevo histórico ${ }^{47}$ como fundamento del futuro papel de París.

Es, pues, la historia la que explica esa "supremacía de París" que da título al siguiente capítulo del texto de Hugo. Y esa supremacía tiene una fecha: 1789, hito clave, pivote en el que la historia ha girado tomando como eje París48. Sólo en 1789 culmina esa lenta pero inexorable salida de las tinieblas que se venía preparando desde todas las épocas anteriores de la historia de la ciudad. La Revolución ha llevado a cabo una gigantesca labor de saneamiento, que ha creado un punto de retorno en el que se hace imposible cualquier tentativa de vuelta atrás: incluso el París "de mascarada y bacanal" del Segundo Imperio (un tema que había tenido un claro precedente en 1853 con la dura crítica de Hugo a la frivolidad de los bulevares de Les Châtiments) no tiene, para Hugo, más importancia que la de un poco de neblina antes de la espléndida e inevitable aurora. Es, igualmente, la
Revolución francesa (a pesar de su componente de violencia originaria: si Atenas ha construido el Partenón, París ha demolido la Bastilla) la que ha hecho que el populacho o la plebe haya devenido pueblo, y eso es lo que le diferencia de ciudades como Roma, Venecia, Nápoles, Londres o Tréveris (cuya presencia en esa lista no deja de ser sorprendente) ${ }^{49}$.

Algunas de las metáforas cósmicas tan caras a Hugo se escalonan para dar forma a esta superioridad moral: París es, así, vela en la que confluyen los vientos de toda la civilización, o condensador en el que la nebulosa se hace estrella. Además, siguiendo una tradición ya presente con fuerza en Balzac ${ }^{50}$, la ciudad se personifica en un ser vivo, y se pueden por tanto predicar de ella rasgos psicológicos o morales tales como la volición, la premeditación o la paciencia para perseguir objetivos a largo plazo.

El progresivo engrandecimiento físico de París a lo largo de la historia es una imagen de su engrandecimiento moral. 1789 simboliza también, en este sentido, la resistencia de la ciudad a las sucesivas tentativas del poder de encerrarla en murallas. En un movimiento irresistible desde el centro hacia el exterior, que nos permite evocar las sutiles reflexiones de Georges Poulet sobre las tensiones de la forma circular ${ }^{51}$, la filosofía irradia desde el centro de París hasta su exterior, más fuerte que cualquier barrera física.

Este movimiento se traslada también al esencial problema político de la relación entre París y Francia, ya que su historia es igualmente la historia de su negativa a todos los intentos de descentralización tanto de la propia ciudad (una operación que Hugo compara con el cortar un diamante en trozos más pequeños) como de la nación (París constituye el centro de una esfera que es Francia y que le debe ante todo obediencia).

Gracias a esta historia, París reúne, para Hugo, todos los títulos para presentarse como condensación histórica de las tres grandes ciudades "rítmicas": Jerusalén, Atenas y Roma, representantes respectivamente de los tres principios básicos de la Verdad, la Belleza y la Grandeza. Son ciudades cuya idea básica no ha muerto, sino que ha venido de algún modo a reencarnarse en ese París que, pertrechado con las mismas, se dispone a asumir su misión de nuevo faro de 
la humanidad: una función de diseminación de esa idea de la Razón representada por la sucesión de la trilogía Rabelais, Molière, Voltaire, de siembra de chispas de luz en medio de las tinieblas, de atizador del incendio del progreso y de su extensión por todo el mundo. Y una misión que queda simbolizada, desde el punto de vista arquitectónico, por la comparación entre la cúpula de la basílica de San Pedro y la del Panteón de Soufflot: si la primera es, ciertamente, más grande, la segunda es la cobertura del talento y la utilidad social.

Los argumentos en pro de la superioridad de París y de su función mundial culminan en el último capítulo del texto de Hugo, la "Declaración de paz", que termina por consolidar la idea básica de la utopía pacifista. El París del inmediato futuro, en el que se aprecia por todas partes la presión del ideal humanitario (como el pulgar de Miguel Ángel se revela, nos dice Hugo, en el non finito de sus bloques), respira progreso y poco a poco ha arrojado fuera de sí todo lo que obstaculizaba dicho progreso ${ }^{52}$. Ha guardado para sí los aspectos beneficiosos de la tecnología y ha eliminado los perjudiciales: respeta el ferrocarril, pero derriba las barreras y controles.

Para Hugo, este sueño pacifista es no sólo realizable sino inminente. Como ya había expuesto en Los Miserables, el sueño no es sino la prefiguración de la realidad futura y lo imposible la primera fase de lo posible. Todas las utopías de ayer (piénsese en la fotografía, el telégrafo, etc.) son las realidades de hoy. $Y$ este rasgo de factibilidad viene volcado por Hugo en dos imágenes metáforicas, una artística y la otra de índole cósmica. El sueño utópico es comparado, en efecto, al trabajo inicial de desbaste de un bloque sobre el que luego se tallará la escultura ${ }^{53}$, pero también a las sucesivas fases en que un fluído cósmico va precipitándose y pasando a un estado líquido y luego sólido: exactamente lo que le ocurre a la utopía cuando llega a un nivel tal de posibilidad de realización que sale de las manos del filósofo y pasa a las del estadista.

Y su primer episodio no es otro que la propia Exposición universal de 1867. Hugo parece no conocer los detalles del edificio proyectado por Krantz y Eiffel como sede de la misma, ya que propone añadir en cada una de sus "cua- tro esquinas" (esquinas inexistentes en el pabeIlón oval) sendas estatuas de Homero, Dante, Shakespeare y Beethoven, más otra de Voltaire ante la puerta de entrada. Pero para él los problemas arquitectónicos de la feria son secundarios al lado de la cuestión principal: el año de la exposición se contrapone al sangriento año anterior, 1866, que ha estado marcado por el signo de la guerra austro-prusiana. A la carnicería de Sadowa, el brillante espectáculo de París enfrenta la "convención pacífica" de las naciones (incluidas las "embrionarias"). Victor Hugo consideraba a los cañones prusianos exhibidos en la misma tan sólo un accidente en un recorrido que había de ver inevitablemente el triunfo de la locomotora sobre las máquinas de muerte.

La realidad inmediata fue muy otra. Como vimos anteriormente, Hugo había evocado la figura mítica de la Esfinge para expresar la complejidad de la historia parisina. Poco podía sospechar en 1867 que, cuatro años más tarde, esa misma Esfinge simbolizaría la brusca quiebra de su utopía pacifista tras las duras pruebas del asedio prusiano y de la Comuna: en 1871 Gustave Doré volcó en su cuadro L'Énigme la más clara expresión de horror y de perplejidad ante el panorama de la urbe incendiada (Fig. 8). En cuanto al propio Victor Hugo, si en 1870 sintetizaba ya en Les Années funestes lo esencial de su crítica antihaussmanniana y, sobre todo, antinapoléonica, en 1872 nos dará, con la publicación de L'Année térrible ${ }^{54}$, toda la medida del horror del París incendiado y su profunda identificación con esos nuevos miserables que son los mártires communards, pero también su inquebrantable confianza, en medio de la desesperación, en un futuro de paz y libertad capitaneado por un nuevo París. ${ }^{55}$

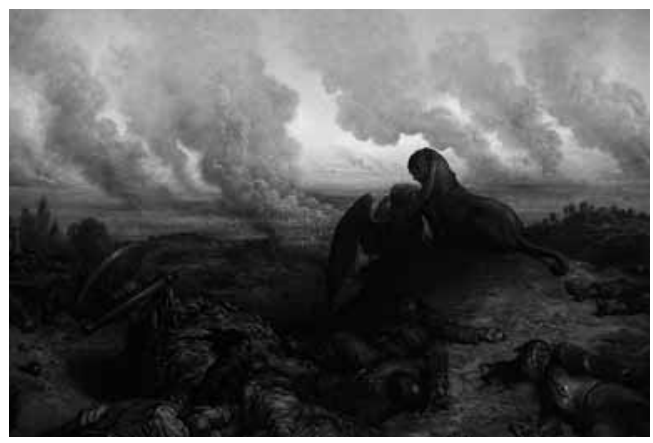

Fig. 8. Gustave Doré, L'Énigme, 1871 (París, Musée d'Orsay) 


\section{NOTAS}

1 Sobre el filón utópico en la reflexión urbana del siglo XIX sigue siendo insoslayable, a pesar de las numerosísimas contribuciones de las últimas décadas, el libro seminal de F. Choay, L'Urbanisme. Utopies et réalités, Seuil, París, 1965 (ed. española El Urbanismo. Utopías y realidades, Lumen, Barcelona, traducción de Luis del Castillo, 1976. Vid. igualmente las obras esenciales de R. Trousson, Voyages aux pays de nulle part. Histoire littéraire de la pensée utopique, Éditions de I'Université Libre de Bruxelles, Bruselas, 1979 (ed. española Historia de la literatura utópica. Viajes a paises inexistentes, Península, Barcelona, traducción de Carlos Manzano, 1995); V. Fortunati y R. Trousson, Dictionary of Literary Utopias, Honoré Champion, París, 2000; L. Tower Sargent y R. Schaer (eds.), Utopie. La quête de la société idéale en Occident, Bibliothèque Nationale de France / Fayard, París, 2000; M. Riot-Sarcey, T. Bouchet y A. Picon, Dictionnaire des utopies, Larousse, Paris, Larousse, 2008.

${ }^{2}$ La bibliografía sobre la imagen del París del siglo XIX en la literatura es inabarcable y crece sin cesar al ritmo del cada vez mayor interés por las relaciones entre literatura y ciudad. Me limitaré por ello a citar a continuación algunas obras que me han resultado de especial utilidad para la elaboración de este trabajo. P. Citron, La poésie de Paris dans la littérature française. De Rousseau à Baudelaire, Les Éditions de Minuit, París, 1961, 2 vols; AA.VV., Paris au XIXe siècle. Aspects d'un mythe litterraire, Presses Universitaires de Lyon, Lyon, 1984; AA.V., Paris et le phenomène des capitales littéraires. Carrefour ou dialogue des cultures, Université de ParisSorbonne (Paris IV), París, 1984, 2 vols.; C. Prendergast, Paris and the Nineteenth Century, Blackwell, Oxford (UK) y Cambridge (Mass.), 1992; P.P. Ferguson, Paris as Revolution. Writing the nineteenthcentury City, University of California Press, Berkeley, 1994; G. Durieux, Le roman de Paris à travers les siècles et la littérature, Albin Michel, París, 2000; K. Stierle, La capitale des signes. Paris et son discours, Éditions de la Maison des Sciences de l'Homme, París, 2001; P. Hamon, Imageries. Littérature et image au
XIXe siècle, José Corti, París, 2001; J.-P. Bernard, Les deux Paris. Les représentations de Paris dans la seconde moitié du XIXe siècle, Champ Vallon, París, 2001; E. Hazan, L'invention de Paris. II n'y a pas de pas perdus, Seuil, París, 2002; R. Tamborrino, Parigi nell'Ottocento. Cultura architettonica e città, Marsilio, Venecia, 2005; D. Harvey, Paris, capital de la Modernidad, Akal, Madrid, 2008. Actualmente se encuentra en prensa mi propio libro París, siglo XIX: los escritores y la metrópolis, de próxima aparición en Abada editores, Madrid.

${ }^{3}$ J. Fabien, Paris en songe, E. Dentu éditeur, 1863; edición castellana, con estudio introductorio de Carolina del Olmo, París en sueños, trad. de Blanca Navarro, Círculo de Bellas Artes, Madrid, 2011.

${ }^{4}$ La extraordinaria visión, mezcla de utopía y distopía, del París de 1960 escrita por Jules Verne seguramente en 1862 ó 1863 y rechazada en su momento por el editor Jules Hetzel permaneció inédita y olvidada hasta la recuperación del manuscrito en 1986. J. Verne, Paris au XXe siècle, Hachette, París, 1994; edición castellana, con estudio introductorio de Piero Gondolo della Riva, París en el siglo $X X$, trad. de Julia Escobar, Planeta, Barcelona, 1995.

${ }^{5}$ En los últimos tiempos, frente al mito pertinaz de un Haussmann como autor único de la modernización de París, se tiende a poner de manifiesto toda la importancia de las reformas urbanas emprendidas anteriormente al Segundo Imperio. Vid. en especial F. Paul-Lévy, La ville en croix. De la révolution de 1848 à la rénovation haussmannienne. Élements pour une problématique générale, Librairie des Méridiens, París, 1984; P. Pinon, «Les préfets parisiens et I'urbanisme. Chabrol et Rambuteau», en J. Des Cars y P. Pinon, Paris-Haussmann : le «pari d'Haussmann », Éditions du Pavillon de l'Arsenal, Paris, 1991; K. Bowie (ed.), La modernité avant Haussmann. Formes de l'espace urbain à Paris, 1801 1853, París, Éditions Recherches, 2001; N. Papayanis, Planning Paris before Haussmann, The Johns Hopkins University Press, Baltimore, 2004.

${ }^{6}$ Paris dans sa splendeur. Monuments, vues pittoresques, scènes historiques. Descriptions et histoire, Henri
Charpentier Imprimeur-Éditeur, París, 1857-1861, 3 vols. Entre los colaboradores de la obra se encuentran, además de Victor Fournel, personajes de primera fila como Merimée, Sainte-Beuve, Viollet-le-Duc, Lassus, Albert Lenoir, Edmond About o Édouard Fournier.

${ }^{7}$ V. Fournel, La deportations des morts. Le Prefet de la Seine et les cimetieres de Paris, Armand Le Chevalier éditeur, París, 1870. Vid. al respecto M. Ragon, L'espace de la mort, Albin Michel, París, 1981, pp. 277-286, así como el cap. IV, "La mort à Paris", de J.-P.-A. Bernard, Les deux Paris. Les représentations de Paris dans la seconde moitié du XIXe siècle, Champ Vallon, París, 2001, pp. 129-175.

${ }^{8} \mathrm{~V}$. Fournel, Paris et ses ruines en mai 1871, Charpentier, París, 1872.

${ }^{9} \mathrm{~V}$. Fournel, Les cris de Paris. Types et physionomies d'autrefois, FirminDidot, Paris, 1887 (ed. moderna Les Éditions de Paris, París, 2003).

${ }^{10} \mathrm{Vid}$. O. Balaÿ, L'espace sonore de la ville au XIXe siècle, À la croisée, Aubenas, 2003

${ }^{11} \mathrm{~V}$. Fournel, Les cris..., op. cit., p. 70. Salvo indicación en contra, todas las traducciones del francés han sido realizadas directamente por el autor de este artículo.

${ }^{12} \mathrm{~V}$. Fournel, Paris nouveau et Paris future, Jacques Lecoffre Libraire-Éditeur, París, 1865.

13 «Le vieux Paris n'est plus (la forme d'une ville / Change plus vite, hélas!, que le coeur d'un mortel)» («El viejo París ya no existe (la forma de una ciudad / cambia más rápidamente, jay!, que el corazón de un mortal)») (Ch. Baudelaire, «Le Cygne», Les Fleurs du Mal, Auguste Poulet-Malassis éditeur, París, 1857). Los estudios sobre Baudelaire y París, a partir de las bien conocidas reflexiones pioneras de Walter Benjamin, son excesivamente numerosos como para intentar aquí una reseña de los mismos. Me limitaré por ello a remitir a mi propia tentativa de síntesis de esta problemática, en J. Calatrava, «Poeta y ciudad: Baudelaire, pintor de la vida moderna», Sileno. Variaciones de arte y pensamiento, 1, 1996, pp. 54-62, así como a la reciente contribución esencial de A. Pizza, Parigi e Baudelaire. Letterature, arti e critica nella città moderna, Edizioni Unicopli, Milán, 2017. 
${ }^{14}$ Op. cit., pp. 231-257.

${ }^{15}$ Se trata de un motivo habitual tanto en la literatura de viajes (Montesquieu, por ejemplo, recomendaba, al llegar a una ciudad, subir ante todo a la torre más alta y contemplar la visión panorámica de conjunto) como en las visiones poéticas urbanas. En este último sentido, podríamos citar el ejemplo, bien conocido en el momento en que Fournel escribe, del poema Paris de Alfred de Vigny, escrito en 1831 y aparecido en 1837 en la segunda edición de los Poèmes antiques et modernes, en cuyo incipit el viajero-narrador contempla el panorama nocturno de París desde la cima de una torre no identificada que resume, en realidad, toda la larga serie de torres míticas. Este motivo de la visión desde lo alto, referido al París de Haussmann, encontrará su continuidad en la célebre escena de La Curée de Émile Zola (1871) en la que el personaje de Aristide Saccard contempla desde Montmartre la ciudad que está a punto de ser sometida a los «destripamientos» haussmannianos (para un análisis de dicha escena, J. Calatrava, «En los orígenes de la metrópolis moderna: Émile Zola y el París de Haussmann», en J. Calatrava y J.A. González Alcantud (eds.), La ciudad: paraíso y conflicto, Abada editores, Madrid, 2007, pp. 229-258).

${ }^{16}$ De hecho, en el París del siglo XX tal y como lo retrata Jules Verne, tal empresa aparece ya realizada gracias a un gigantesco canal que ha dado origen a la construcción de un «puerto de mar» en Grenelle (J. Verne, op. cit., p. 111).

17 Sobre las repercusiones literarias y culturales de esta bipolaridad, A. Djoutachkovitch e Y. Leclerc (eds)., ParisProvince. Topographie littéraire du XIXe siècle, Publications de I'Université de Rouen, Rouen, 2000.

${ }^{18}$ Con ello, Fournel comparte -seguramente $\sin$ ser consciente de ellouno de los rasgos principales del prácticamente contemporáneo (1859) plan de ensanche de Ildefons Cerdà para Barcelona: la exigencia de la sección cuadrada de la calle (aunque en el caso del ingeniero catalán las dimensiones eran de $20 \times 20 \mathrm{~m}$.), que sería precisamente el primero de los rasgos innovadores de su plan en ser obviado debido a la presión de los intereses inmobiliarios.
${ }^{19}$ E. Hénard, Études sur les transformations de Paris, publicados en París en fascículos sueltos entre 1903 y 1909; edición castellana Estudios sobre las transformaciones de París y otros escritos de urbanismo, Fundación Caja de Arquitectos, Barcelona, 2012.

${ }^{20}$ Precisamente uno de los cambios más claramente percibidos por los parisinos durante los grands travaux de Haussmann fue el de los peligros que se arrostraban ahora al querer cruzar calles no sólo llenas de escombros, zanjas y obras de todo tipo sino también sacudidas por un movimiento frenético que contrastaba con la quietud de la ciudad tradicional. El tema de estos «peligros» que acechaban al peatón constituyó el objeto de numerosas caricaturas (Daumier, Crafty) y reflexiones literarias (como es el caso célebre del poema en prosa de Baudelaire Perte d'auréole).

${ }^{21}$ Recuérdese, por poner un solo ejemplo, la ciudad utópica de Franceville, completamente organizada en torno a la más rigurosa asepsia, en J. Verne, Les Cinq-cent millions de la Bégum, Pierre-Jules Hetzel éditeur, París, 1879. Vid. al respecto J. Calatrava, "Casas de papel», Sileno. Variaciones de arte $y$ pensamiento, 6, 1999, pp. 31-36.

${ }^{22}$ Paris nouveau et Paris futur, op. cit., p. 252.

${ }^{23}$ Vid. W. Schivelbusch, Lichtblicke: zur Geschichte der Künstlichen Helligkeit im 19. Jahrundert, Carl Hanser Verlag, Munich-Viena, 1983; S. Delattre, Les douze heures noires. La nuit à Paris au XIXe siècle, Albin Michel, París, 2003.

${ }^{24}$ Paris nouveau et Paris futur, op. cit., p. 246

${ }^{25}$ W. Benjamin, Obra de los Pasajes, Abada editores, Madrid, 2 vols., 2013 y 2015.

${ }^{26}$ V. Hugo, «Introduction», en Paris Guide par les principaux écrivains et artistes de la France, Librairie Internationale, París, y A. Lacroix, Verboeckhoven et Cie. Éditeurs, Bruselas-Leipzig-Livorno, 1867, 2 vols., pp. I-XLIV.

27 Plasmadas, sobre todo, en los diferentes textos sobre las destrucciones patrimoniales escritos entre 1825 y 1834 y reunidos en ese mismo año en Guerre aux démolisseurs!, Renduel, París, 1834 (ed. moderna V. Hugo, Guerre aux démolisseurs!, L'Archange Mino- taure, Montpellier, 2002). Vid. R. Recht (dir.), Victor Hugo et le débat patrimonial, Somogy éditions d'art-Institut National du Patrimoine, París, 2003.

${ }^{28}$ A. Delrieu y A. García, «Victor Hugo, Notre-Dame et I'architecture», en Littératures. Annales de la faculté des lettres de Toulouse 19, 2, 1972, pp. 4148; G. Rosa, «Notre-Dame de Paris. Texture d'archives en architecture», Lendemains. Etudes comparées sur la France, 3, 10, 1978, pp. 15-31; C. Bernard, «De I'architecture à la littérature. La topographie parisienne dans «Notre-Dame de Paris» de Victor Hugo», en M. Grimaud (ed.), Victor Hugo 1 : Approches critiques contemporaines, Lettres modernes Minard, Paris, 1984, pp. 103-138; J. C. Kessler, «Babel and Bastille: architecture as metaphor in Hugo's Notre-Dame de Paris», French Forum, 11, 1986, pp. 183-197; B. Dieterle, «Un gothique restauré. Littérature, architecture et restauration dans Notre-Dame de Paris», en M. Schmeling y M. Schmitz-Emans (eds.), Das Visuelle Gedächtnis der Literatur, Köningshausen und Neumann, Würzburg, 1999, pp. 204-214; A. C. Gaspar Seganfredo, Ananké et le symbolisme de l'architecture dans Nôtre-Dame de Paris de Victor Hugo, tesis doctoral Universidade Federal do Tio Grande do Sul, Porto Alegre, 2004.

${ }^{29}$ À l'Arc de Triomphe, poema escrito en 1834 y publicado en 1837 en Les Voix intérieures (George Rouillier Libraire, Lausanne, 1837). Vid. S. Gaudon, "James Pradier, Victor Hugo et I'Arc de Triomphe de l'Etoile», en Revue d'histoire littéraire de la France, 68, 5, 1985, pp. 713-725. I. Rouge-Ducos, L'Arc de Triomphe de l'Étoile: art et histoire, Faton, Dijon, 2008.

${ }^{30}$ Les Misérables, A. Lacroix, Verboeckhoven \& Ce., Bruselas, 1862 (ed. esp. Los Miserables, traducción Aurora Alemany, Orbis, Barcelona, 1982; las citas de esta obra en las siguientes notas están referidas a esta edición española).

${ }^{31}$ Lamartine, preocupado por la posible reacción de Victor Hugo, con quien le ligaba una estrecha amistad, solicitó de antemano su benevolencia para realizar una crítica detallada de la obra. La respuesta positiva de Hugo, expresada en su conocida carta a Lamartine de 24 de junio de 1862, permitió a éste redac- 
tar, entre noviembre de 1862 y marzo de 1863, cinco largas Entretiens, con un total de más 300 páginas. Vid. R. Trousson, Lamartine critique des Misérables, Académie royale de langue et de littérature françaises de Belgique, Bruselas, 1995 (on line: http://www.arllfb.be/ ebibliotheque/communications/trousson141095.pdf).

32 «Muerte, me sirvo de tí pero te odio. Ciudadanos, no habrá en el porvenir ni tinieblas, ni rayos, ni ignorancia feroz, ni talión sangriento. Como no existirá Satanás, tampoco existirá Miguel. En el porvenir, nadie matará a nadie, la tierra resplandecerá, el género humano amará. Llegará, ciudadanos, el día en que todo será concordia, armonía, luz, alegría y vida. Y para que llegue este día nosotros debemos morir» (op. cit., Cuarta Parte, Libro XI, cap. VIII, p. 236). Sobre la imagen de París en LoS Miserables, vid. especialmente K. Stierle, op. cit., pp. 322-340.

${ }^{33}$ Op. cit., Quinta Parte, libro I, cap. V, pp. 299-300.

34 «Hemos domado a la hidra, y le hemos dado el nombre de vapor; hemos domado al dragón, y le hemos dado el nombre de locomotora; estamos a punto de domar el grifo, pues ya ha caído en nuestras manos, y hemos cambiado su nombre por el de globo» (ibid., p. 300).

${ }^{35}$ Ibid., Quinta Parte, libro I, cap. $X X$, p. 339.

${ }^{36}$ A.-J.-B.-B. Parent-Duchatelet, Essai sur les cloaques ou egouts de la ville de Paris. envisagés sur le rapport de I'hygiène publique et de la topographie médicale de cette ville, Crévot, París, 1824.

${ }^{37} \mathrm{~S}$. Barles, La Ville délétère, Champ Vallon, Seyssel, 1999; J. Bourgeois-Gavardin, Les Boues de Paris sous l'Ancien Régime : Contribution à l'histoire $d u$ nettoiement urbain au xviie et xviiie siècles, EHESS, Paris, 1985, 2 volumes; M.S. Armstrong, "Hugo's 'égouts' and Le Ventre de Paris», The French Review, 69, 3, feb. 1996, pp. 394-408; M. Gandy, "The Paris sewers and the rationalization of urban space», Transactions of the Institute of British Geographers, 24, 1999, pp. 23-44; K. Chatzis, La Pluie, le métro et l'ingénieur : contribution à I'histoire de l'assainissement et des transports urbains, L'Harmattan, Paris,
2000; D. Reid, Égouts et égoutiers de Paris, Presses universitaires de Rennes, Rennes, 2014; A. Clément y G. Thomas (eds.), Atlas du Paris souterrain, Parigramme, Paris, 2001; D.L. Pike, Subterranean cities. The world beneath Paris and London, 1800-1945, Cornell Un. Press, Ithaca, 2005

${ }^{38}$ Sobre la visión de la arquitectura y su papel en la obra de Victor Hugo, J. Mallion, Victor Hugo et l'art architectural, Presses Universitaires de France, 1962; T. B. Raser, "Narrative evasions of esthetics. Victor Hugo 's appreciations of architecture», French Forum, 13, 1988, pp.339-350; J. C. Kessler, «Cette Babel du monde. Visionnary architecture in the poetry of Victor Hugo", Nineteenth-Century French Studies, 19, 1991, pp.417-431; J. M. Losada Goya, «Victor Hugo ou les paradoxes de I'architecture. Du livre de pierre au livre de papier», Travaux de littérature, 12, 1999, pp.163-171; J. Prungnaud, «Hugo et l'imaginaire de l'architecture», en D. Peyrache-Leborgne y Y. Jumelais (eds.), Victor Hugo ou les frontières effacées, Pleins Feux, Nantes, 2002, pp. 255-268; Ch. Brière, Victor Hugo et le roman architectural, Honoré Champion, Paris, 2007.

\section{${ }^{39}$ Introduction, cit., p. XXXIV.}

$40 \mathrm{~J}$. Seebacher, "L'universalité de Paris: Victor Hugo et l'Exposition de 1867", Revue du Musée d'Orsay, 48, 1, 1989, pp. 63-68; J. Seebacher, "Capitale de la violence: le Paris de Victor Hugo", Cahiers de l'Association Internationale des Études Françaises, $\mathrm{n}^{\circ} 42$ (1990), p. 43; F. Chenet- Faugeras (ed.), Victor Hugo et l'Europe de la pensée, Nizet, Paris, 1995; D. Fernandez, «Le Paris de Victor Hugo: une splendide utopie», en Victor Hugo, Paris, Bartillat, Paris, 2001; J. Neefs, «Paris Guide, 1867», en J.-J. Lefrère y M. Pierssens (eds.), Paris, sa vie, son œuvre: huitième colloque des Invalides, 19 novembre 2004, Tusson, Du Lérot, 2005, pp. 69-74; E. Ousselin, «Victor Hugo's European Utopia», Nineteenth-Century French Studies, 34, 2005-2006, pp. 32-43; C. Bouliane, Décombres de l'avenir et projets rudéraux: les métamorphoses de Paris chez Verne, Hugo et Zola, tesis doctoral Université de Montréal, 2009; S. Artes, «Victor Hugo's Paris: Reviving Palingenesis», French Forum, 35, 1, 2010, pp. 1-16
${ }^{41}$ «Ahora bien, en mi prefacio indico, y ese es mi tema, el papel de París en el pasado, en el presente y en el futuro» (Victor Hugo, Correspondance (18491866), T. 2, Paris, Ollendorff, 1950, p. 568).

${ }^{42}$ El pacifismo de Victor Hugo tiene una larga trayectoria previa, con numerosas reflexiones que anticipan la utopía de la paz mundial plasmada en el texto de 1867. Uno de los más claros precedentes es su intervención en el Congreso de Amigos de la Paz Universal que tuvo lugar en París en agosto de 1849 (Congrès des Amis de la Paix Universelle réuni à Paris en 1849, Librairie de Guillaumin et Cie., París, 1850).Vid. C. Millet (ed.), Hugo et la guerre, Editions Maisonneuve \& Larose, Paris, 2002.

${ }^{43}$ Sobre la importancia del pensamiento sansimoniano en las visiones de París en las décadas centrales del XIX, A. Picon, Les saint-simoniens. Raison, imaginaire, utopie, Éditions Belin, París, 2002.

${ }^{44}$ Introduction, cit., p. XXXIII. Entre esos personajes que odian al París siempre móvil, Hugo cita a Joseph De Maistre.

45 «Bajo el París actual, el antiguo París se distingue como el viejo texto entre las ruinas del nuevo» (Introduction, op. cit., p. X).

${ }^{46}$ « ¿No puede hacerse un film apasionante a partir del plano de París, del desarrollo en orden temporal de sus distintas configuraciones, del condensar el movimiento de sus calles, sus bulevares, sus pasajes y sus plazas a lo largo de un siglo en el espacio de una media hora? Y ¿no es ese el trabajo del flâneur?» (W. Benjamin, Obra de los pasajes, op. cit., C I, 9, vol. 1, p. 169).

${ }^{47}$ «El comienzo de París es contiguo a la decadencia de Roma» (Introduction, op. cit., p. VII).

${ }^{48}$ Como es bien sabido, la mitificación de la Revolución Francesa sería el tema justamente de la última novela de Victor Hugo: Quatre-vingt-treize, Michel Lévy Frères, París, 1874.

49 Jean Mallion destaca, sin embargo, el especial interés de Hugo por esta ciudad alemana y su pasado imperial romano en los viajes que realiza en 1862 y 1863 (J. Mallion, op. cit., pp. 309-311) 
${ }^{50}$ Por ejemplo, en Ferragus (18331834), como he estudiado en J. Calatrava, «Balzac urbanista: el espacio parisino en Ferragus», $P+C$. Proyecto y ciudad. Revista de temas de arquitectura, 2, 2011, pp. 5-22.

${ }^{51} \mathrm{G}$. Poulet, Les métamorphoses $d u$ cercle, Plon, París, 1961.

${ }^{52}$ Hugo recurre aquí una vez más a la metáfora geológica: "Como los glaciares, que tienen un no sé qué de castidad grandiosa y que, con un mo- vimiento insensible pero irresistible y desconocido, rechazan a su morrena los bloques erráticos, París ha arrojado fuera todas las inmundicias, la voirie, los mataderos, la pena de muerte» (Introduction, op. cit., p. XXXV)

${ }^{53}$ «Lo realizable es un bloque que hay que desbastar y del que los soñadores comienzan el modelo» (Introduction, op. cit., p. XXXVII). Esta imagen de la talla del bloque estaba igualmente presente en Los Miserables (ed. cast. cit., I, VI, 1).
${ }^{54}$ He utilizado la edición francesa posterior que reúne ambas obras: V. Hugo, L'Année térrible / Les Années funestes, 1854-1870, Nelson éditeurs, París, s.d.

55 «Où le sphinx dit: Chaos, Paris dit: Liberté!» («Donde la esfinge dice: Caos, París dice: ¡Libertad»), V. Hugo, L'Anné Térrible, op. cit., poema Paris incendié, p. 211. 